\title{
Microstructure and Durability Performance of Mortars with Volcanic Powder from Calbuco Volcano (Chile) after 4 Hardening Years
}

\author{
Rosa María Tremiño ${ }^{1}$, Teresa Real-Herraiz ${ }^{2}\left(\mathbb{D}\right.$, Viviana Letelier ${ }^{3}(\mathbb{C})$ and José Marcos Ortega ${ }^{1, *(1)}$ \\ 1 Departamento de Ingeniería Civil, Universidad de Alicante, Ap. Correos 99, 03080 Alicante, Spain; \\ rmta2@alu.ua.es \\ 2 Instituto de Matemática Multidisciplinar, Universidad Politécnica de Valencia, Camino de Vera s/n, \\ 46022 Valencia, Spain; tereaher@upv.es \\ 3 Departamento de Obras Civiles, Universidad de la Frontera, Av. Fco. Salazar, Temuco 01145, Chile; \\ viviana.letelier@ufrontera.cl \\ * Correspondence: jm.ortega@ua.es; Tel.: +34-96-5903-400 (ext. 2470)
}

check for

updates

Citation: Tremiño, R.M.

Real-Herraiz, T.; Letelier, V.;

Ortega, J.M. Microstructure and

Durability Performance of Mortars

with Volcanic Powder from Calbuco

Volcano (Chile) after 4 Hardening

Years. Materials 2021, 14, 1751.

https://doi.org/10.3390/ma14071751

Academic Editors: Miguel Bravo, Rui Vasco Silva and António P. C. Duarte

Received: 23 February 2021

Accepted: 25 March 2021

Published: 2 April 2021

Publisher's Note: MDPI stays neutra with regard to jurisdictional claims in published maps and institutional affiliations.

Copyright: (c) 2021 by the authors. Licensee MDPI, Basel, Switzerland. This article is an open access article distributed under the terms and conditions of the Creative Commons Attribution (CC BY) license (https:// creativecommons.org/licenses/by/ $4.0 /)$.

\begin{abstract}
One of the most popular ways to lessen the impact of the cement industry on the environment consists of substituting clinker by additions. The service life required for real construction elements is generally long, so it would be interesting to obtain information about the effects of new additions after a hardening period of several years. Analyzed here are the effects of the incorporation of volcanic ashes, coming from Calbuco volcano's last eruption (Chile), as clinker replacement, in the durability and pore structure of mortars, after approximately 4 hardening years (1500 days), in comparison with reference specimens without additions. The substitution percentages of clinker by volcanic powder studied were $10 \%$ and $20 \%$. The microstructure was characterized with mercury intrusion porosimetry and impedance spectroscopy. In order to evaluate the pozzolanic activity of the volcanic powder after 1500 days, differential thermal analyses were performed. Water absorption after immersion, steady-state diffusion coefficient and length change were also studied. In accordance with the results obtained, the $10 \%$ and $20 \%$ substitution of clinker by volcanic powder from the Calbuco volcano showed beneficial effects in the mortars after 4 years, especially regarding the microstructure and chloride diffusion, without noticeable influence in their water absorption.
\end{abstract}

Keywords: volcanic powder; Calbuco volcano; very long term; microstructure; durability

\section{Introduction}

At present, the cement industry still constitutes an important pollutant sector [1,2], and it is necessary that this industry contributes to the current worldwide goals regarding global warming reduction. Therefore, for lessening its greenhouse gas emissions and making the cement industry and construction sector in general more sustainable, several strategies have been developed, such as the research on eco-friendly materials, which has experienced great progress in recent years [3-5].

With respect to cement-based materials, one of the most popular ways of reducing the greenhouse gas emissions, due to their manufacture, consists of substituting clinker with supplementary cementitious materials [6-9]. Some of them are residues generated in other industrial processes, so its reuse is also beneficial from an environmental perspective. Among the supplementary cementitious materials available, it is important to highlight silica fume [10,11], ground granulated blast-furnace slag [12,13], and fly ash [14], which have all been commonly used in recent decades. Despite that, developing alternatives to these classical additions is still an important topic of research. Among others, some examples of these new supplementary cementitious materials are brick powder [15], rice husk ash [16], glass powder [17,18], red mud [19], etc. 
In relation to the possible use of powders coming from volcanic materials as an addition to cement, research has shown that they would provide adequate service properties [20,21]. On the one hand, it has been reported that these volcanic powders can develop pozzolanic activity [20] and improve the durability of cement-based materials [22,23]. Nevertheless, other works indicated that the incorporation of volcanic powders as a substitution of clinker produced a reduction incompressive strength [24,25] and an increase in porosity [21,26], recommending percentages of this addition up to $20 \%$, inwhich an approximate $23 \%$ reduction in strength has been reported [25]. In addition to this, it is important to highlight that the majority of these studies have analyzed the effects of volcanic powder at relatively short hardening ages [27].

On the other hand, the service life required for construction elements, belonging to real structures, buildings, and other engineering works is generally long [28]. Then, to assess if these new additions to cement-based materials, such as volcanic powder, are suitable for use in real construction elements, it would be very interesting to obtain information about their behavior in the very long term, after a hardening period of several years. Furthermore, this could be particularly relevant in the case of pozzolanic materials.

The main purpose of this research is to study the effects of the incorporation of volcanic powder, coming from the last eruption of the Calbuco volcano (Chile), as clinker replacement, in the durability and pore structure of mortars after approximately 4 hardening years (1500 days), compared to reference mortars without additions. The analyzed percentages of clinker substituted by volcanic powder were $10 \%$ and $20 \%$. The pore structure of the mortars was characterized using mercury intrusion porosimetry and the non-destructive impedance spectroscopy technique. For evaluating the development of the possible pozzolanic activity of the volcanic powder at the end of the time period studied, differential thermal analyses were performed. With respect to the durability of the mortars, the steadystate diffusion coefficient, determined from the resistivity of the water-saturated samples and the water absorption after immersion, were obtained. Lastly, the length change in the mortars was measured after 1500 hardening days for assessing the possible effects of the volcanic powder addition in this respect.

\section{Materials and Methods}

\subsection{Materials and Sample Preparation}

The volcanic powder (VP) studied in this research came from Calbuco volcano's last eruption $\left(41^{\circ} 20^{\prime} \mathrm{S}, 72^{\circ} 37^{\prime} \mathrm{W}, 2003\right.$ m.a.s.l.). This volcano is situated in the southern Andes, between the cities of Ensenada and Puerto Montt in Chile. The dates of the last subplinian eruption of this volcano were April 22nd-23rd, 2015. Porphyritic-basaltic andesite ( $55 \%$ by weight of $\mathrm{SiO}_{2}$ ) [29] was detected in the erupted debris. This fallout mostly affected the volcano's northeast area, although the finest ashes reached southern Chile and Argentinean Patagonia, where they mainly settled. The distribution of the particle size of the debris showed particle fractions ranging between 3 and $350 \mu \mathrm{m}$ [30]. In this study, the volcanic powder was sieved, and the particles used as addition were those with sizes smaller than $75 \mu \mathrm{m}$. The chemical components of the VP are shown in Table 1 [27], whereas the size distribution of the powder is represented in Figure 1 [27].

Table 1. Chemical components of volcanic powder.

\begin{tabular}{cc}
\hline Components & Value \\
\hline $\mathrm{Fe}_{2} \mathrm{O}_{3}$ & $11.00 \%$ \\
$\mathrm{CaO}$ & $8.27 \%$ \\
$\mathrm{Al}_{2} \mathrm{O}_{3}$ & $14.54 \%$ \\
$\mathrm{SiO}_{2}$ & $57.76 \%$ \\
$\mathrm{~K}_{2} \mathrm{O}$ & $2.14 \%$ \\
$\mathrm{Na}_{2} \mathrm{O}$ & $2.41 \%$ \\
$\mathrm{MgO}$ & $2.44 \%$ \\
$\mathrm{TiO}_{2}$ & $1.42 \%$ \\
\hline
\end{tabular}




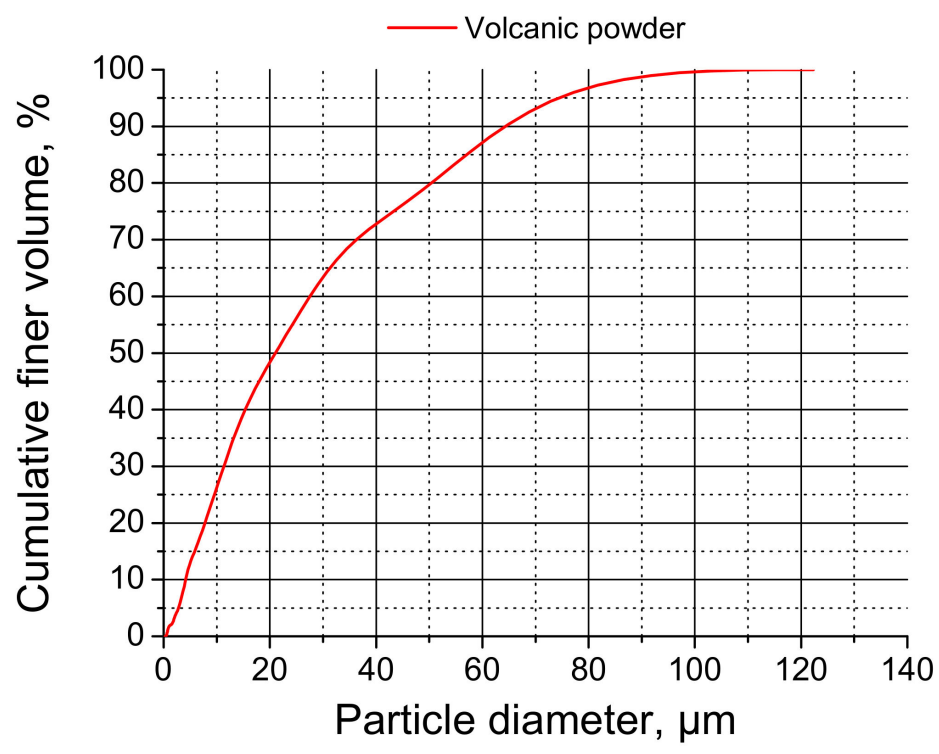

Figure 1. Size distribution of particles of studied powder.

Three kinds of mortar were studied in this research, in which Calbuco's VP and Portland cement were combined. This cement was type CEM I 42.5 R [31]. Firstly, a reference mortar without VP, designed as REF in the results and discussion sections, was prepared. On the other hand, mortars with two different VP binders were also made. These binders incorporated $10 \%$ and $20 \%$ in weight as cement CEM I 42.5 R substitution, named VP10 and VP20, respectively. A water/cement ratio of 0.5 was used for all of the studied mortars, as well as an aggregate/cement ratio equal to 3 . The fine quartz sand accomplished the provisions of standard UNE-EN 196-1 [32] and was provided by the company Normensand (Beckum, Germany) [33-35].

Two types of sample were cast. One of them consisted of cylindrical samples with dimensions $10 \mathrm{~cm}$ in diameter, and $15 \mathrm{~cm}$ in height. In addition, prismatic specimens with the dimensions of $25 \mathrm{~mm} \times 25 \mathrm{~mm} \times 285 \mathrm{~mm}$ were also made. All of them were stored in a chamber at $20^{\circ} \mathrm{C}$ at a $95 \%$ relative humidity (RH) during the initial $24 \mathrm{~h}$. After that curing period, they were de-moulded. In order to optimize the total amount of material required and their storage, cylindrical samples were cut to obtain slices with $1 \mathrm{~cm}$ in height. Finally, the samples were kept in an optimum laboratory condition $\left(20^{\circ} \mathrm{C}\right.$ and $\left.100 \% \mathrm{RH}\right)$ until 1500 hardening days (approximately 4 years), when they were tested. This condition consisted of storing the specimens in hermetically sealed containers, which contained distilled water in their bottom part to achieve a $100 \%$ relative humidity environment. The mortar samples were placed into the containers, avoiding contact with water by using a rack above the water level. In addition, these containers were kept in a chamber at a controlled temperature of $20^{\circ} \mathrm{C}$. The dimensions of the hermetically sealed containers used were $325 \mathrm{~mm} \times 265 \mathrm{~mm} \times 150 \mathrm{~mm}$.

\subsection{Mercury Intrusion Porosimetry}

Mercury intrusion porosimetry is useful for obtaining data regarding the pore network of materials [36-38]. Here, the porosimetry test was performed using a Poremaster-60 GT porosimeter manufactured by Quantachrome Instruments (Boynton Beach, FL, USA). The specimens were oven-dried at $50^{\circ} \mathrm{C}$ over $48 \mathrm{~h}$ before performing the test. The results analyzed in this research were total porosity, pore size distribution, and percentage of $\mathrm{Hg}$ retained at the end of the experiment. The pore size distribution was analyzed, taking into account the next intervals: $<10 \mathrm{~nm}, 10-100 \mathrm{~nm}, 100 \mathrm{~nm}$ to $1 \mu \mathrm{m}, 1-10 \mu \mathrm{m}, 10 \mu \mathrm{m}$ to $0.1 \mathrm{~mm}$, and $>0.1 \mathrm{~mm}[39,40]$. Two measurements were made on each type of mortar at the hardening age studied. Pieces taken from the $1 \mathrm{~cm}$ disks, with irregular shapes, were tested. The total weight of the pieces tested in each of the measurements was approximately $1.5 \mathrm{~g}$. 


\subsection{Impedance Spectroscopy}

The impedance spectroscopy technique is used for obtaining data related to the microstructure of cement-based materials [41-44]. In this research, the impedance spectroscopy measurements were done with an analyzer model Agilent 4294A (Agilent Technologies, Kobe, Japan). This device allows measurements between $10^{-14}$ and $0.1 \mathrm{~F}$. The electrodes were circular (diameter $8 \mathrm{~cm}$ ). They were made with flexible graphite, which was fixed to a copper disk, also measuring $8 \mathrm{~cm}$ in diameter. The range of frequencies was $100 \mathrm{~Hz}$ to $100 \mathrm{MHz}$.

Contacting and non-contacting measurements were conducted [41]. The experimental records were fit to the equivalent circuits shown in Figure 2a,b [41], which consisted of several resistances and capacitances [41]. The resistance $\mathrm{R}_{1}$ provides data about the percolating pores in the material [41], the resistance $R_{2}$ provides information about the overall pores [41], the capacitance $C_{1}$ provides information regarding a sample's solid fraction [41], and the $C_{2}$ capacitance is associated with the pores' surface contacting with the electrolyte present inside the pore network [42]. In this work, regarding the pore structure characterization, only the results of the parameters $R_{2}, C_{1}$ and $C_{2}$, determined using the non-contacting method have been analyzed, on account of their greater accuracy. The $R_{1}$ resistance, which can be determined using the contacting method, was only used for calculating the steady-state chloride diffusion coefficient in water-saturated specimens, as will be explained in Section 2.6. Eight different slices, measuring $1 \mathrm{~cm}$ in height, were analyzed with this technique for each mortar type.

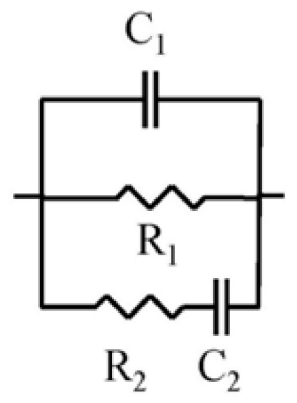

(a)

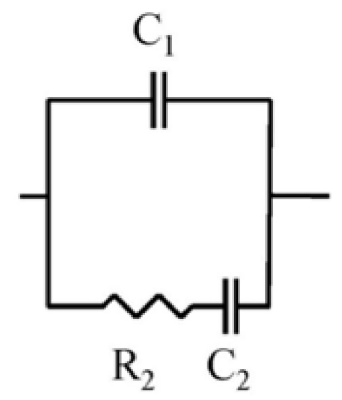

(b)

Figure 2. (a) Equivalent circuit for the contacting method [18,27]; (b) Equivalent circuit for the non-contacting method [18,27]. Reprinted with permission from [18,27] 2018 MDPI.

\subsection{Differential Thermal Analysis}

The differential thermal analyses were conducted with a simultaneous TG-DTA model TGA/SDTA851e/SF/1100 from Mettler Toledo (Columbus, OH, USA), which allows operation from room temperature, up to $1100^{\circ} \mathrm{C}$. The heating ramp selected was $20^{\circ} \mathrm{C} / \mathrm{min}$ up to $1000{ }^{\circ} \mathrm{C}$ in $\mathrm{N}_{2}$ atmosphere. The curve weight derivate versus temperature was determined. Three measurements were made on each type of mortar at the hardening age studied. The powder samples tested with this technique were obtained from milling pieces taken from disks of $1 \mathrm{~cm}$ in thickness. The total weight of powder in each one the measurements was approximately $20 \mathrm{mg}$.

\subsection{Water Absorption}

The absorption after immersion was determined following the procedure described in the ASTM Standard C642-06 [45]. Six pieces, taken from slices of $1 \mathrm{~cm}$ in height, were tested for each kind of mortar studied. 


\subsection{Steady-State Diffusion Coefficient}

The steady-state chloride diffusion coefficient was determined from the electrical resistivity of the samples. The resistivity was calculated from the impedance resistance $R_{1}$ measured in water saturated samples. As explained previously, the resistance $R_{1}$ is directly related to the crossing pores of the material [41] and is therefore equivalent to the electrical resistance of the sample [46]. This test has been successfully used in several research works for different types of cement-based materials [46,47]. For each binder, six different samples of $1 \mathrm{~cm}$ in thickness were tested. Finally, the steady-state diffusion coefficient was obtained using the following Equation [48]

$$
\mathrm{D}_{\mathrm{S}}=\frac{2 \times 10^{-10}}{\rho}
$$

where $D_{s}$ is the chloride steady-state diffusion coefficient through the sample $\left(\mathrm{m}^{2} / \mathrm{s}\right)$, and $\rho$ is the electrical resistivity of the specimen $(\Omega \cdot m)$.

\subsection{Shrinkage/Expansion}

In order to assess if the incorporation of volcanic powder from the Calbuco volcano resulted in the development of the expansion or shrinkage phenomena in the mortars, their length change was measured after 1500 hardening days. For each mortar type, six specimens with dimensions measuring $25 \mathrm{~mm} \times 25 \mathrm{~mm} \times 285 \mathrm{~mm}$ were tested. The length change in percentage after 1500 hardening days was determined from the measurements performed with a length comparator according to ASTM Standard C596-01 [49].

\section{Results}

\subsection{Mercury Intrusion Porosimetry}

The total porosity results after 1500 days are represented in Figure 3. This porosity was slightly greater for the VP20 mortars in comparison to the REF and VP10 ones. Despite that, the total porosity was relatively similar for the different series studied.

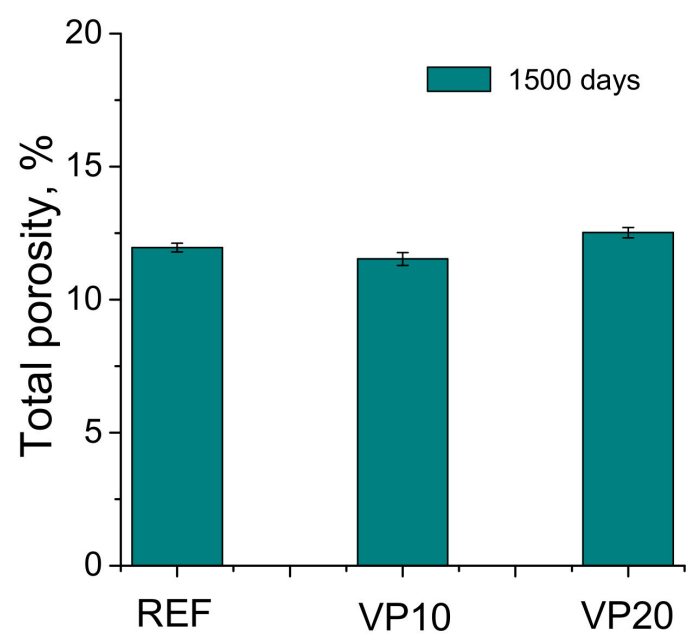

Figure 3. Total porosity results for the analyzed series.

Regarding the pore size distributions of the analyzed mortar series, they are depicted in Figure 4. The proportion of pores with lower sizes was higher for specimens which incorporated volcanic powder in comparison with REF mortars. In this regard, it is important to highlight the greater percentage of pores with diameters in the range of $<10 \mathrm{~nm}$, noted for VP10 and VP20 mortars. In view of these results, the addition of volcanic powder gave a more refined pore network to the mortars after 1500 hardening days. 


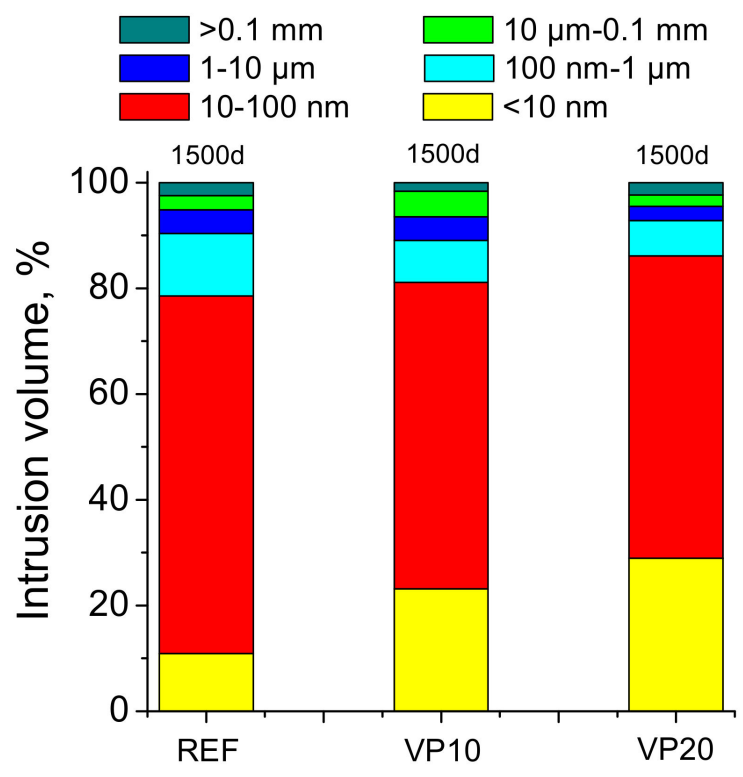

Figure 4. Pore size distributions noted for the series studied.

The results of the percentage of mercury retained at the end of the porosimetry test are depicted in Figure 5. This percentage was greater for specimens with the addition, in comparison to those taken as reference. The highest percentage of mercury retained was noted for VP20 mortars.

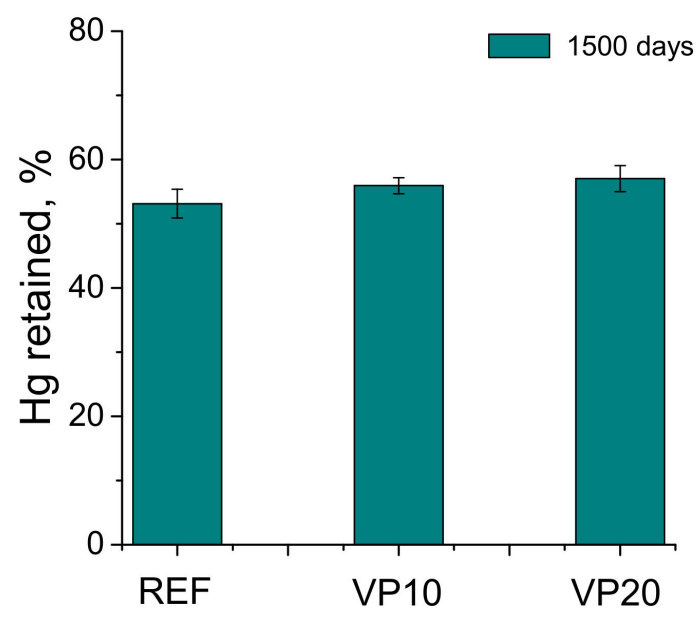

Figure 5. Results of percentage of mercury retained at the end of porosimetry test for the analyzed series.

\subsection{Impedance Spectroscopy}

The results of capacitance $C_{1}$ can be observed in Figure 6 . This capacitance was slightly higher as the percentage of volcanic powder in the mortars rose. Nevertheless, very low differences between the different binders have been noted in the results of capacitance $C_{1}$. 


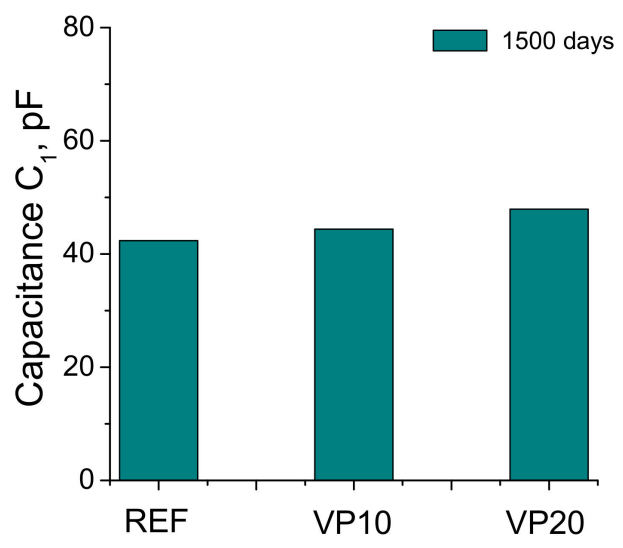

Figure 6. Results of capacitance $C_{1}$ for the mortar series studied.

In relation to capacitance $C_{2}$, its results have been represented in Figure 7 . The greatest value of this capacitance was observed for the VP20 series, followed by VP10. The mortars of the REF series showed the lowest value of this parameter.

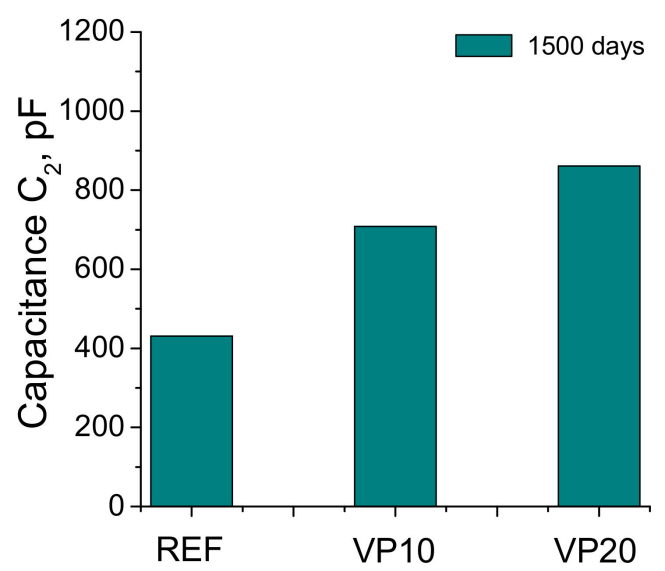

Figure 7. Capacitance $C_{2}$ values for the REF, VP10 and VP20 specimens.

The results of impedance resistance $R_{2}$ can be observed in Figure 8 . This resistance was higher for specimens with volcanic powder after 1500 hardening days, in comparison with reference ones. In addition to this, the value of this parameter increased with the volcanic powder proportion in the binder, showing the VP20 mortars the greatest resistance $R_{2}$.

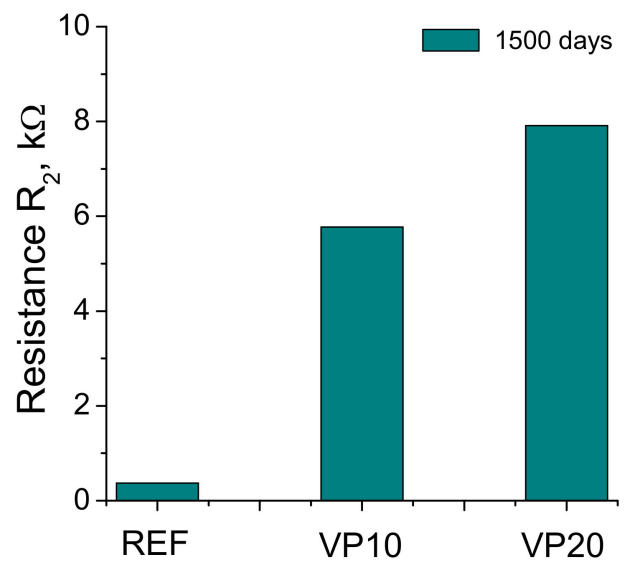

Figure 8. Resistance $\mathrm{R}_{2}$ results noted for the mortars tested. 


\subsection{Differential Thermal Analysis}

The derivate of the weight versus temperature curves obtained for the analyzed mortar series after 1500 days are depicted in Figure 9. The portlandite peak area of this curve was lower as the percentage of clinker replacement by volcanic powder increased.

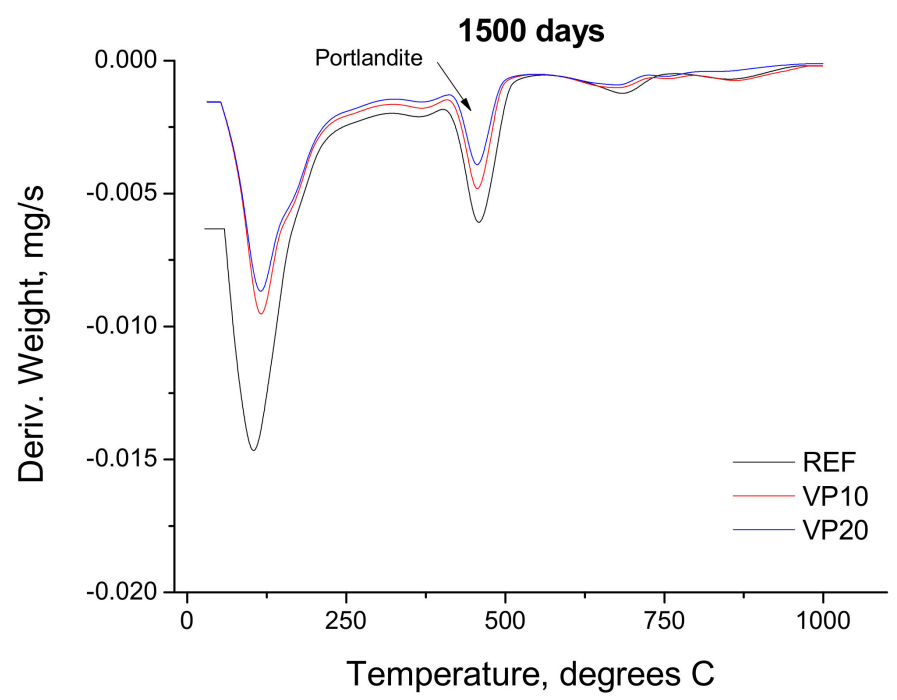

Figure 9. Derivate of weight versus temperature curve obtained for REF, VP10 and VP20 mortars after 1500 hardening days.

\subsection{Steady-State Chloride Diffusion Coefficient}

The results of the steady-state chloride diffusion coefficient obtained from the sample's resistivity for the analyzed series in the very long term have been represented in Figure 10. This coefficient was greater for mortars taken as a reference, in comparison to those which incorporated volcanic powder. The lowest diffusion coefficient was observed for specimens with the greater percentage of volcanic powder (VP20 mortars).

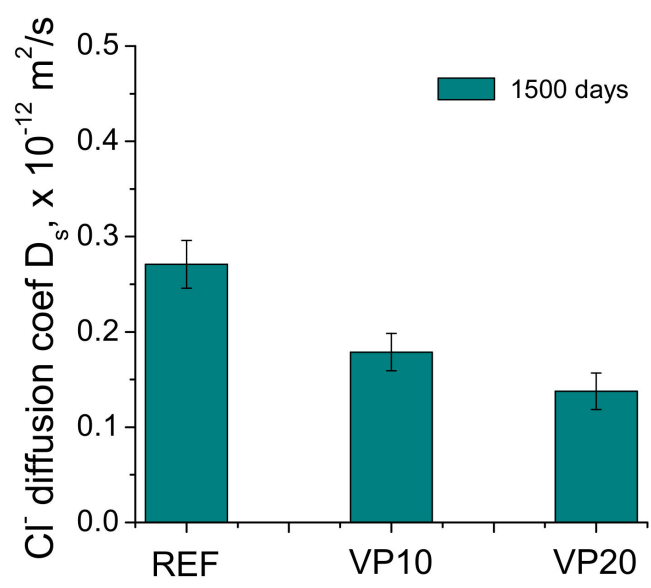

Figure 10. Steady-state chloride diffusion coefficients noted for the binders tested.

\subsection{Water Absorption after Immersion}

The percentages of water absorption after immersion, obtained for the mortar series analyzed after 1500 hardening days, are represented in Figure 11. This absorption was slightly greater for VP20 series with respect to REF and VP10 mortars. In spite of this, the differences between the three binders studied were overall scarce. 


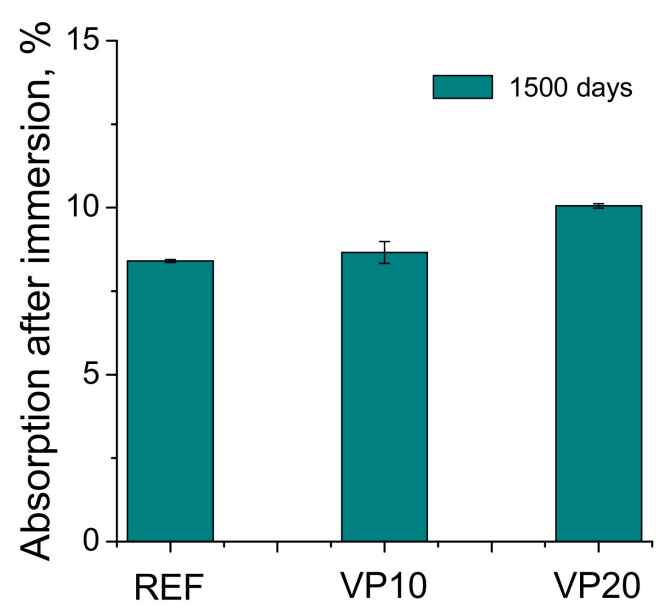

Figure 11. Percentage of absorption after immersion for the series analyzed.

\subsection{Shrinkage/Expansion}

The percentage of length change noted for the different binders studied is depicted in Figure 12. All the mortars showed an expansion during the analyzed time period. The greatest expansion was obtained for the reference series, while the smallest corresponded to the VP20 binder.

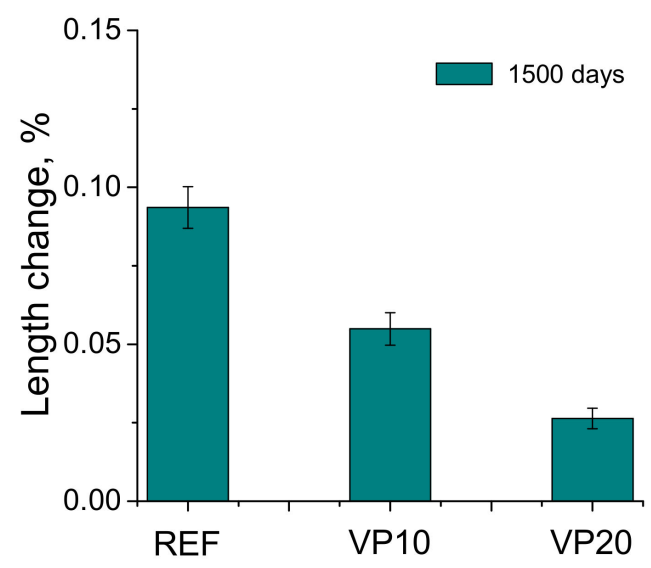

Figure 12. Length change noted for the mortar series analyzed after 1500 hardening days.

\section{Discussion}

\subsection{Microstructure Characterization}

Regarding the mercury intrusion porosimetry technique, the similar total porosity in the very long term noted for the mortars tested (see Figure 3) would indicate that they would have a similar fraction of solids and overall volume of pores, independently of the binder used. In this regard, the incorporation of $20 \%$ of volcanic powder in the binder would not entail a noticeable increase in the porosity, compared to reference specimens, in keeping with other research [26]. On the other hand, the distributions of pores by size obtained with this technique, after 1500 hardening days (see Figure 4), would reveal a greater pore refinement in the microstructure produced by the volcanic powder addition, as would suggest the greater proportion of finer pores, mainly those with sizes lower than $10 \mathrm{~nm}$, noted for the VP10 and VP20 specimens, in comparison with reference ones. In addition to this, the results of the percentage of $\mathrm{Hg}$ at the end of the mercury intrusion porosimetry test (see Figure 5) would corroborate this higher pore refinement of mortars with volcanic powder. This parameter gives data regarding the tortuosity of the pore structure of the material [41]. Therefore, the highest percentages of $\mathrm{Hg}$ retained, obtained in the VP10 and VP20 samples, would indicate more tortuosity in their microstructure, 
directly related to their high pore refinement. The results of pore size distributions and $\mathrm{Hg}$ retained would also show that the microstructure refinement was greater as the proportion of clinker replaced by volcanic powder increased.

The microstructure refinement produced by the addition of volcanic powder after 1500 hardening days could be a result of the development of its pozzolanic reactions. These reactions would form solid phases as products, closing the pore network of the mortars and increasing the relative presence of pores with lower diameters. This pozzolanic activity of the volcanic powder after 4 hardening years would also be suggested by the differential thermal analyses performed. With this technique, it has been noted lower areas of the portlandite peak in the curves derivate of the weight versus the temperature for series with volcanic powder, compared to those without an addition (see Figure 9). This pozzolanic activity would be in keeping with other research [20,21], in which the effects of additions coming from volcanic materials in the short term have been analyzed.

Furthermore, the results of impedance spectroscopy showed coincidences with the mercury intrusion porosimetry results previously discussed. On one hand, the parameter $\mathrm{C}_{1}$ gives data regarding global fraction of solids in the sample [41], independently of its pore size distribution. As has been previously described, scarce differences between the different studied mortars were observed in this capacitance (see Figure 6). This would suggest that global fractions of solids were very similar after 1500 hardening days for the different studied series. This result would agree with that obtained for porosity, which also revealed slight differences in the total volume of pores, independently of the addition of volcanic powder. The incorporation of volcanic powder produced scarce effects on the global porosity, whereas it increased the refinement of the microstructure, as noted by other supplementary cementitious materials, such as fly ash [50].

The impedance capacitance $C_{2}$ is associated with the internal pores surface contacting with the electrolyte, which fills the material's pore network [42]. Therefore, a rise in this surface produced by the formation of solids as rough structures on the preexisting walls of the pores, due to the progressive development of pozzolanic and hydration reactions, would entail higher values of this capacitance $C_{2}$ [43]. Furthermore, for specimens with similar global porosity and greater pore refinement, the higher presence of finer pores would also produce a higher global pore surface, giving greater capacitance to $C_{2}$ values. This parameter showed higher values for VP10 and VP20 specimens after 1500 hardening days compared to reference mortars, which became greater as the percentage of volcanic powder in the binder rose (see Figure 7). This result would indicate that the internal pore surface in specimens with this addition was higher than that for referenced ones, suggesting that the addition of volcanic powder would produce a greater microstructure refinement, as a consequence of the progress of its pozzolanic reactions [20,21]. This would agree with the pore size distributions and $\mathrm{Hg}$ retained results previously discussed.

Finally, the $\mathrm{R}_{2}$ resistance gives information about the material's pore structure [42], The values of $R_{2}$ are higher as greater is the presence of pores with smaller diameters. As previously described, the specimens with volcanic powder showed higher resistances $R_{2}$ in comparison with the reference ones (see Figure 8), and the highest values of this resistance corresponded to VP20 mortars. These results would also coincide with those discussed for capacitance $\mathrm{C}_{2}$, pore size distributions and percentage of $\mathrm{Hg}$ retained, revealing the pore refinement produced by this addition.

\subsection{Durability-Related Parameters}

With regard to the analyzed durability-related parameters of the series with volcanic powder in the very long term, the steady-state chloride diffusion coefficient exhibited smaller values for VP10 and VP20 specimens, in comparison with referenced ones (see Figure 10). As happened with some microstructural parameters, this coefficient decreased as the content of volcanic powder in the mortars increased. This result would agree with those obtained by other authors at short hardening ages [22,23]. It may be related to the high microstructural refinement observed for VP10 and VP20 specimens, which could be 
a consequence of the development of the volcanic-powder pozzolanic reactions [20,21] already discussed. The presence of a noticeable percentage of pores with lower sizes would entail a more difficult diffusion of aggressive chloride ions throughout the material, which would lead to lower values of the steady-state diffusion coefficient, as previously observed. This result would be relevant, because chlorides constitute one of the most damaging agents which could affect the durability of cementitious materials and, as was observed, the addition of volcanic powder as clinker replacement, improved the performance of the mortars at this point after1500 hardening days.

In relation to the percentage of absorption after immersion, in general, the differences between the studied mortars were scarce (see Figure 11), which would be in keeping with the results of impedance capacitance $C_{1}$, as well as total porosity, suggesting that the overall volume of pores in the studied series was relatively similar, irrespective of the binder. In view of the length change results observed for the different series studied (see Figure 12), a length increase was noted for all of them, showing a slight expansion after 1500 hardening days. This could be expected due to the storage of the specimens at an optimum condition during the studied time period. Despite that, it is noticeable that mortars with volcanic powder showed less deformation than referenced ones.

Lastly, considering the results previously discussed, the incorporation of volcanic powder from the Calbuco volcano in mortars, with up to $20 \%$ of clinker replacement, would have beneficial effects after 1500 hardening days, in terms of the refinement of pore network and chloride diffusion. Furthermore, this addition would not noticeably worsen other properties, such as total porosity and water absorption by immersion. It is important to highlight that these results, in the very long term, would be interesting for evaluating the possible application of volcanic powder coming from the Calbuco volcano in real cement-based construction elements, which are generally required over a long service life. Furthermore, the use of this volcanic powder as a clinker replacement would also contribute to sustainability, providing additional advantages in relation to the protection of the environment.

\section{Conclusions}

The main conclusions that can be obtained from the results previously discussed can be summed up as follows:

- Mortars with the addition of volcanic powder from the Calbuco volcano showed a more refined pore network after 1500 hardening days, in comparison with referenced specimens, in view of the results of the impedance $C_{2}$ capacitance and $R_{2}$ resistance, as well as the pore size distributions obtained by mercury intrusion porosimetry;

- The higher microstructure refinement produced by the incorporation of volcanic powder from the Calbuco volcano could be due to the pozzolanic activity of this addition, as indicated by the differential thermal analyses after 1500 hardening days, which produced a greater proportion of finer pores;

- The global porosity and solid fraction was very similar for all of the studied mortars after 1500 days, irrespective of the presence of volcanic powder in the binder, as showed in the total porosity results, obtained from mercury porosimetry, and the impedance capacitance $\mathrm{C}_{1}$;

- The use of binders with volcanic powder from the Calbuco volcano produced a reduction of the steady-state chloride diffusion coefficient after 4 years, compared to mortars without this addition. Moreover, this parameter was lower as the percentage of volcanic powder in the binder rose. This improvement in the behaviour regarding the chloride diffusion could be produced by the more refined pore network caused by the addition of volcanic powder in the mortars;

- The incorporation of volcanic powder did not noticeably affect the performance of the mortars with respect to the water absorption after immersion in the very long term, suggesting an overall volume of pores that is fairly similar for the analyzed series; 
- In accordance with the results obtained in this work, the $10 \%$ and $20 \%$ clinker replacement by volcanic powder from the Calbuco volcano would have beneficial effects in the performance of mortars after approximately 4 hardening years, especially regarding their microstructure development and chloride ingress resistance, without considerably affecting their water absorption, with the additional advantages regarding the protection of the environment.

Author Contributions: Conceptualization, V.L. and J.M.O.; methodology, V.L., T.R.-H. and J.M.O.; investigation, R.M.T., T.R.-H., V.L. and J.M.O.; data curation, R.M.T. and J.M.O.; writing-original draft preparation, R.M.T.; writing-review and editing, J.M.O.; supervision, T.R.-H. and J.M.O.; funding acquisition, J.M.O. and V.L. The results included in this paper have been obtained in the PhD thesis carried out by R.M.T. at University of Alicante (Spain), under the supervision of J.M.O. and T.R.-H. All authors have read and agreed to the published version of the manuscript.

Funding: This work was supported by the Conselleria de Educación, Investigación, Cultura y Deporte (at present re-named as Conselleria de Innovación, Universidades, Ciencia y Sociedad Digital) de la Generalitat Valenciana (Spain) (grant code GV/2019/070) and by the Agencia Nacional de Investigación y Desarrollo de Chile (ANID) (grant number FONDECYT REGULAR 1211135).

Institutional Review Board Statement: Not applicable.

Informed Consent Statement: Not applicable.

Data Availability Statement: Data sharing not applicable.

Acknowledgments: Authors wish to thank Cementos Portland Valderrivas S.A. for providing the ordinary Portland cement used in this study.

Conflicts of Interest: The authors declare no conflict of interest.

\section{References}

1. Benhelal, E.; Shamsaei, E.; Rashid, M.I. Challenges against $\mathrm{CO}_{2}$ abatement strategies in cement industry: A review. J. Environ. Sci. China 2021, 104, 84-101. [CrossRef]

2. Zhang, C.-Y.; Yu, B.; Chen, J.-M.; Wei, Y.-M. Green transition pathways for cement industry in China. Resour. Conserv. Recycl. 2021, 166, 105355. [CrossRef]

3. Valipour, M.; Shekarchi, M.; Arezoumandi, M. Chlorine diffusion resistivity of sustainable green concrete in harsh marine environments. J. Clean. Prod. 2017, 142, 4092-4100. [CrossRef]

4. Sobolev, K.; Türker, P.; Soboleva, S.; Iscioglu, G. Utilization of waste glass in ECO-cement: Strength properties and microstructural observations. Waste Manag. 2007, 27, 971-976. [CrossRef] [PubMed]

5. Palankar, N.; Ravi Shankar, A.U.; Mithun, B.M. Durability studies on eco-friendly concrete mixes incorporating steel slag as coarse aggregates. J. Clean. Prod. 2016, 129, 437-448. [CrossRef]

6. Liu, Y.; Sidhu, K.S.; Chen, Z.; Yang, E.-H. Alkali-treated incineration bottom ash as supplementary cementitious materials. Constr. Build. Mater. 2018, 179, 371-378. [CrossRef]

7. Yang, K.-H.; Jung, Y.-B.; Cho, M.-S.; Tae, S.-H. Effect of supplementary cementitious materials on reduction of $\mathrm{CO}_{2}$ emissions from concrete. J. Clean. Prod. 2015, 103, 774-783. [CrossRef]

8. Faleschini, F.; Zanini, M.A.; Brunelli, K.; Pellegrino, C. Valorization of co-combustion fly ash in concrete production. Mater. Des. 2015, 85, 687-694. [CrossRef]

9. Ortega, J.M.; Sánchez, I.; Climent, M.A. Influence of environmental conditions on durability of slag cement mortars. In Proceedings of the 2nd International Conference on Sustainable Construction Materials and Technologies, Ancona, Italy, 28-30 June 2010.

10. Ganjian, E.; Pouya, H.S. Effect of magnesium and sulfate ions on durability of silica fume blended mixes exposed to the seawater tidal zone. Cem. Concr. Res. 2005, 35, 1332-1343. [CrossRef]

11. Ortega, J.M.; Esteban, M.D.; Rodríguez, R.R.; Pastor, J.L.; Ibanco, F.J.; Sánchez, I.; Climent, M.Á. Influence of silica fume addition in the long-term performance of sustainable cement grouts for micropiles exposed to a sulphate aggressive medium. Materials 2017, 10, 890. [CrossRef]

12. Çakır, Ö.; Aköz, F. Effect of curing conditions on the mortars with and without GGBFS. Constr. Build. Mater. 2008, 22, 308-314. [CrossRef]

13. Ortega, J.M.; Pastor, J.L.; Albaladejo, A.; Sánchez, I.; Climent, M.A. Durability and compressive strength of blast furnace slag-based cement grout for special geotechnical applications. Mater. Constr. 2014, 64. [CrossRef]

14. Berndt, M.L. Properties of sustainable concrete containing fly ash, slag and recycled concrete aggregate. Constr. Build. Mater. 2009, 23, 2606-2613. [CrossRef] 
15. Navrátilová, E.; Rovnaníková, P. Pozzolanic properties of brick powders and their effect on the properties of modified lime mortars. Constr. Build. Mater. 2016, 120, 530-539. [CrossRef]

16. Xu, W.; Lo, Y.T.; Wang, W.; Ouyang, D.; Wang, P.; Xing, F. Pozzolanic Reactivity of Silica Fume and Ground Rice Husk Ash as Reactive Silica in a Cementitious System: A Comparative Study. Materials 2016, 9, 146. [CrossRef]

17. Lu, J.-X.; Zhan, B.-J.; Duan, Z.-H.; Poon, C.S. Using glass powder to improve the durability of architectural mortar prepared with glass aggregates. Mater. Des. 2017, 135, 102-111. [CrossRef]

18. Ortega, J.M.; Letelier, V.; Miró, M.; Moriconi, G.; Climent, M.A.; Sánchez, I. Influence of waste glass powder addition on the pore structure and service properties of cement mortars. Sustainability 2018, 10, 842. [CrossRef]

19. Ribeiro, D.V.; Labrincha, J.A.; Morelli, M.R. Potential use of natural red mud as pozzolan for Portland cement. Mater. Res. 2011, 14, 60-66. [CrossRef]

20. Siddique, R. Properties of concrete made with volcanic ash. Resour. Conserv. Recycl. 2012, 66, 40-44. [CrossRef]

21. Kupwade-Patil, K.; Al-Aibani, A.F.; Abdulsalam, M.F.; Mao, C.; Bumajdad, A.; Palkovic, S.D.; Büyüköztürk, O. Microstructure of cement paste with natural pozzolanic volcanic ash and Portland cement at different stages of curing. Constr. Build. Mater. 2016, 113, 423-441. [CrossRef]

22. Anwar Hossain, K.M. Performance of volcanic ash based precast and in situ blended cement concretes in marine environment. J. Mater. Civ. Eng. 2005, 17, 694-702. [CrossRef]

23. Hossain, K.M.A. Blended cement using volcanic ash and pumice. Cem. Concr. Res. 2003, 33, 1601-1605. [CrossRef]

24. Seddik Meddah, M. Durability performance and engineering properties of shale and volcanic ashes concretes. Constr. Build. Mater. 2015, 79, 73-82. [CrossRef]

25. Hossain, K.M.A.; Lachemi, M. Strength, durability and micro-structural aspects of high performance volcanic ash concrete. Cem. Concr. Res. 2007, 37, 759-766. [CrossRef]

26. Kupwade-Patil, K.; Palkovic, S.D.; Bumajdad, A.; Soriano, C.; Büyüköztürk, O. Use of silica fume and natural volcanic ash as a replacement to Portland cement: Micro and pore structural investigation using NMR, XRD, FTIR and X-ray microtomography. Constr. Build. Mater. 2018, 158, 574-590. [CrossRef]

27. Letelier, V.; Ortega, J.M.; Tremiño, R.M.; Henriquéz-Jara, B.I.; Fustos, I.; Real-Herraiz, T.; Moriconi, G.; Climent, M.A.; Sánchez, I. The use of volcanic powder as a cement replacement for the development of sustainable mortars. Appl. Sci. 2020, 10, 1460. [CrossRef]

28. European Committee for Standardization. EN 1992-1-1 Eurocode 2: Design of Concrete Structures-Part. 1-1: General Rules and Rules for Buildings. EN 1992-1-1 Eurocode 2; European Committee for Standardization (CEN): Brussels, Belgium, 2004.

29. Romero, J.E.; Morgavi, D.; Arzilli, F.; Daga, R.; Caselli, A.; Reckziegel, F.; Viramonte, J.; Díaz-Alvarado, J.; Polacci, M.; Burton, M.; et al. Eruption dynamics of the 22-23 April 2015 Calbuco Volcano (Southern Chile): Analyses of tephra fall deposits. J. Volcanol. Geotherm. Res. 2016, 317, 15-29. [CrossRef]

30. Reckziegel, F.; Bustos, E.; Mingari, L.; Báez, W.; Villarosa, G.; Folch, A.; Collini, E.; Viramonte, J.; Romero, J.; Osores, S. Forecasting volcanic ash dispersal and coeval resuspension during the April-May 2015 Calbuco eruption. J. Volcanol. Geotherm. Res. 2016, 321, 44-57. [CrossRef]

31. Asociación Española de Normalización y Certificación. Composición, Especificaciones y Criterios de Conformidad de Los, Cementos Comunes, AENOR UNE-EN 197-1:2011; Asociación Española de Normalización y Certificación: Madrid, Spain, 2011.

32. Asociación Española de Normalización y Certificación. Métodos de Ensayo de Cementos. Parte 1: Determinación de Resistencias Mecánicas, AENOR UNE-EN 196-1:2005; Asociación Española de Normalización y Certificación: Madrid, Spain, 2005.

33. Normensand GmbH Normensand. Available online: https:/ / www.normensand.de/en/home/ (accessed on 20 March 2021).

34. Normensand GmbH Material Information Sheet Normensand. Available online: https://www.normensand.de/fileadmin/ gruppen/Normensand/Downloads/2017-05-09_Normensand_Material-Information-Sheet.pdf (accessed on 20 March 2021).

35. Normensand GmbH Untersuchungsbericht Normensand. Available online: https://www.normensand.de/fileadmin/gruppen/ Normensand/Downloads/Untersuchungsbericht_Gesamtstatistik.pdf (accessed on 20 March 2021).

36. Diamond, S. Mercury porosimetry. Cem. Concr. Res. 2000, 30, 1517-1525. [CrossRef]

37. Ouellet, S.; Bussière, B.; Aubertin, M.; Benzaazoua, M. Microstructural evolution of cemented paste backfill: Mercury intrusion porosimetry test results. Cem. Concr. Res. 2007, 37, 1654-1665. [CrossRef]

38. Horpibulsuk, S.; Rachan, R.; Chinkulkijniwat, A.; Raksachon, Y.; Suddeepong, A. Analysis of strength development in cementstabilized silty clay from microstructural considerations. Constr. Build. Mater. 2010, 24, 2011-2021. [CrossRef]

39. Pedeferri, P.; Bertolini, L. La Durabilità del Calcestruzzo Armato; Mc Graw-Hill Education: Milano, Italy, 2000; ISBN 9788838608452.

40. Ho, L.S.; Nakarai, K.; Duc, M.; Kouby, A.L.; Maachi, A.; Sasaki, T. Analysis of strength development in cement-treated soils under different curing conditions through microstructural and chemical investigations. Constr. Build. Mater. 2018, 166, 634-646. [CrossRef]

41. Cabeza, M.; Merino, P.; Miranda, A.; Nóvoa, X.R.; Sanchez, I. Impedance spectroscopy study of hardened Portland cement paste. Cem. Concr. Res. 2002, 32, 881-891. [CrossRef]

42. Cabeza, M.; Keddam, M.; Nóvoa, X.R.; Sánchez, I.; Takenouti, H. Impedance spectroscopy to characterize the pore structure during the hardening process of Portland cement paste. Electrochim. Acta. 2006, 51, 1831-1841. [CrossRef]

43. Ortega, J.M.; Sánchez, I.; Climent, M.A. Impedance spectroscopy study of the effect of environmental conditions in the microstructure development of OPC and slag cement mortars. Arch. Civ. Mech. Eng. 2015, 15, 569-583. [CrossRef] 
44. Tang, S.W.; Cai, X.H.; He, Z.; Zhou, W.; Shao, H.Y.; Li, Z.J.; Wu, T.; Chen, E. The review of pore structure evaluation in cementitious materials by electrical methods. Constr. Build. Mater. 2016, 117, 273-284. [CrossRef]

45. ASTM. Standard Test Method for Density, Absorption, and Voids in Hardened Concrete, ASTM C642-06; ASTM International: West Conshohocken, PA, USA, 2006; p. 3.

46. Ortega, J.M.; Sánchez, I.; Antón, C.; De Vera, G.; Climent, M.A. Influence of environment on durability of fly ash cement mortars. ACI Mater. J. 2012, 109, 647-656.

47. Ortega, J.M.; Sánchez, I.; Climent, M.A. Durability related transport properties of OPC and slag cement mortars hardened under different environmental conditions. Constr. Build. Mater. 2012, 27. [CrossRef]

48. Andrade, C.; Alonso, C.; Arteaga, A.; Tanner, P. Methodology based on the electrical resistivity for the calculation of reinforcement service life. In Proceedings of the 5th CANMET/ACI International Conference on Durability of Concrete, Supplementary Papers, Barcelona, Spain, 4-9 June 2000; Malhotra, V.M., Ed.; American Concrete Institute: Farmington Hills, MI, USA; pp. $899-915$.

49. ASTM. Standard Test Method for Drying Shrinkage of Mortar Containing Hydraulic Cement, ASTM C596-01; ASTM International: West Conshohocken, PA, USA, 2001; p. 3.

50. Bijen, J. Benefits of slag and fly ash. Constr. Build. Mater. 1996, 10, 309-314. [CrossRef] 